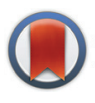

CrossMark

Cite this: Dalton Trans., 2016, 45, 121

\title{
Neutron diffraction and multinuclear solid state NMR investigation into the structures of oxide ion conducting $\mathrm{La}_{9.6} \mathrm{Si}_{6} \mathrm{O}_{26.4}$ and $\mathrm{La}_{8} \mathrm{Sr}_{2} \mathrm{Si}_{6} \mathrm{O}_{26}$, and their hydrated phases
}

\author{
Ben J. Corrie, ${ }^{a}$ J. Felix Shin, ${ }^{\text {a Steve Hull, }}{ }^{\text {K Kevin S. Knight, }},{ }^{\mathrm{b}}$ Maria C. Vlachou, ${ }^{\mathrm{c}}$ \\ John V. Hanna*c and Peter R. Slater ${ }^{{ }^{a}}$
}

\begin{abstract}
Apatite silicates are attracting significant interest as potential SOFC electrolyte materials. They are nonconventional oxide ion conductors in the sense that oxide ion interstitials, rather than vacancies, are the key defects. In this work we compare the structures of $\mathrm{La}_{9.6} \mathrm{Si}_{6} \mathrm{O}_{26.4}$ and $\mathrm{La}_{8} \mathrm{Sr}_{2} \mathrm{Si}_{6} \mathrm{O}_{26}$, both before and after hydration in order to gather information about the location of the interstitial oxide ion site. Neutron diffraction structural studies suggest that in the as-prepared $\mathrm{La}_{8} \mathrm{Sr}_{2} \mathrm{Si}_{6} \mathrm{O}_{26}$ and hydrated $\mathrm{La}_{8} \mathrm{Sr}_{2} \mathrm{Si}_{6} \mathrm{O}_{26}$, the interstitial oxide ion sites are close to the apatite channel centre. For $\mathrm{La}_{9.6} \mathrm{Si}_{6} \mathrm{O}_{26.4}$, a similar site close to the channel centre is observed, but on hydration of this particular sample, the interstitial site is shown to be significantly displaced away from the channel centre towards the $\mathrm{SiO}_{4}$ units. This can be explained by the need for additional displacement from the channel centre to accommodate the large amount of interstitial anions in this hydrated phase. The solid state ${ }^{29} \mathrm{Si}$ MAS NMR spectra are shown to be very sensitive to the different speciation exhibited by the $\mathrm{La}_{8} \mathrm{Sr}_{2} \mathrm{Si}_{6} \mathrm{O}_{26}$ and $\mathrm{La}_{9.6} \mathrm{Si}_{6} \mathrm{O}_{26.4}$ systems, with the former being dominated by regular $\mathrm{SiO}_{4}$ framework species and the latter being dominated by interruptions to this network caused by cation vacancies and interstitials. The corresponding ${ }^{17} \mathrm{O}$ MAS NMR study identifies a strong signal from the $\mathrm{O}$ atoms of the $\mathrm{SiO}_{4}$ groups, thus demonstrating that all of the $\mathrm{O}$ species in these systems are exchangeable $O$ under heterogeneous gas phase conditions. In addition, interstitial $\mathrm{O}$ species attributed to pendant $\mathrm{OH}$ linkages on the Si positions are clearly identified and resolved, and these are removed on dehydration. This observation and assignment is corroborated by corresponding ${ }^{1} \mathrm{H}$ MAS NMR measurements. Overall the neutron diffraction work indicates that the interstitial site location in these apatite silicates depends on the anion content with progressive displacement towards the $\mathrm{SiO}_{4}$ tetrahedra on increasing anion content, while the observation of exchangeable $\mathrm{O}$ on the $\mathrm{SiO}_{4}$ groups is consistent with prior modelling predictions as to the importance on the silicate units in the conduction process.
\end{abstract}

Received 18th August 2015, Accepted 6th November 2015 DOI: $10.1039 / \mathrm{c} 5 \mathrm{dt} 03190 \mathrm{~g}$ www.rsc.org/dalton

\section{Introduction}

The increasing concerns regarding greenhouse gas emissions and diminishing fuel reserves are driving considerable interest in the development of fuel cell technology. In terms of such technology, polymer based fuel cells are the dominant system for transport and portable applications, while Solid Oxide Fuel Cells (SOFCs) are being targeted for stationary power generation. In terms of the electrolyte adopted for SOFC systems,

\footnotetext{
${ }^{a}$ School of Chemistry, University of Birmingham, Birmingham, B15 2TT, UK. E-mail: p.r.slater@bham.ac.uk

${ }^{b}$ ISIS Facility, Rutherford Appleton Laboratory, Chilton, Oxon, UK ${ }^{c}$ Department of Physics, University of Warwick, Coventry CV4 7AL, UK. E-mail:j.v.hanna@warwick.ac.uk
}

traditionally research has focused on perovskite and fluorite systems, with the most widely researched in terms of applications being the fluorite-type materials $\mathrm{ZrO}_{2}$ doped with $\mathrm{Y}_{2} \mathrm{O}_{3}$ (YSZ) or $\mathrm{Sc}_{2} \mathrm{O}_{3}$ (ScSZ), and $\mathrm{CeO}_{2}$ doped with $\mathrm{Gd}_{2} \mathrm{O}_{3}$ (CGO). ${ }^{1,2}$ The key defects in these fluorite systems are oxide ion vacancies which are introduced on partial substitution of $\mathrm{Zr}^{4+}$ / $\mathrm{Ce}^{4+}$ by a trivalent rare earth, and conduction then proceeds via a vacancy hopping mechanism. More recently there has been growing interest in new structure-types displaying high oxide ion conduction. In this respect, apatite-type rare earth silicates and germanates have attracted considerable interest, following the identification of high oxide ion conductivity in the silicates by Nakayama et al., and subsequently in analogous germanates by Arikawa et al. ${ }^{3-5}$ Since the discovery of high oxide ion conductivity in these apatite systems, there has 
been considerable interest in understanding their conduction mechanisms as well as in doping strategies to optimize the conductivities. $^{6-60}$ The ideal apatite stoichiometry can be written $\mathrm{A}_{10}\left(\mathrm{MO}_{4}\right)_{6} \mathrm{O}_{2}(\mathrm{~A}=$ rare earth/alkaline earth; $\mathrm{M}=\mathrm{Ge}, \mathrm{Si})$, and their structure can be viewed as a $\mathrm{A}_{4}\left(\mathrm{MO}_{4}\right)_{6}$ framework (consisting of corner linked $\mathrm{MO}_{4}$ tetrahedra and $\mathrm{AO}_{6}$ trigonal metaprisms), with the remaining $\mathrm{A}_{6} \mathrm{O}_{2}$ units within the "channel" of this framework (Fig. 1). ${ }^{23,24}$ The variation in the size of the $\mathrm{A}_{6} \mathrm{O}_{2}$ "channels" can be correlated with variations in the $\mathrm{AO}_{6}$ metaprism twist angle. ${ }^{23}$ For high oxide ion conductivity, interstitial oxide ion defects are required, which can be achieved through increasing the oxygen content or the introduction of cation vacancies (the latter enhancing Frenkel defect (i.e. displacement of ions off their normal site into interstitial sites) formation). While for the apatite germanates, there is general consensus regarding the location of the interstitial site (neighbouring the $\mathrm{GeO}_{4}$ units), ${ }^{24,25,40,43,49,50}$ for the silicates, a range of sites have been reported, ${ }^{7,11,15,29-31,35,39}$ although there is growing support for a location closer to the channel centre. ${ }^{7,35,39,46}$ One of the difficulties with locating these interstitial sites is the generally low levels of oxygen in these sites, especially for the silicates, where prior studies have suggested a maximum limit close to $0.5 \mathrm{O}$ per formula unit. ${ }^{35}$ In previous work on germanate apatites, we have shown that the interstitial oxygen content can be increased through water

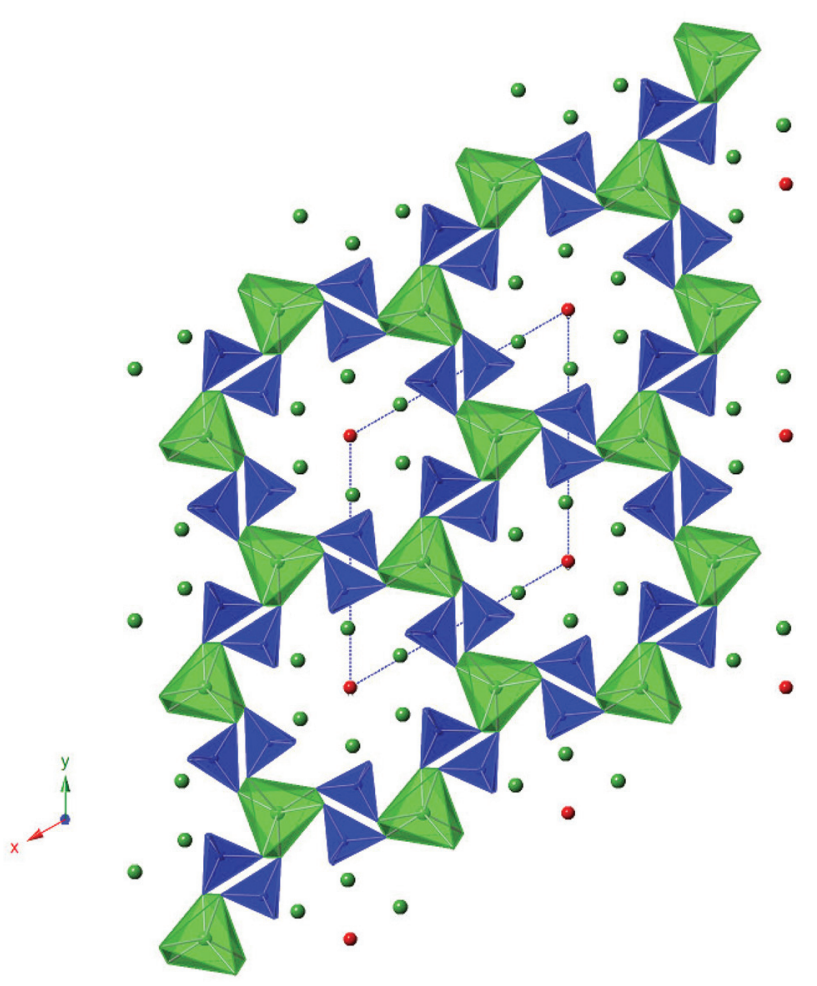

Fig. 1 Illustration of the apatite structure $\left(\mathrm{A}_{10}\left(\mathrm{MO}_{4}\right)_{6} \mathrm{O}_{2}\right.$, showing a $\mathrm{A}_{4}\left(\mathrm{MO}_{4}\right)_{6}$ framework (consisting of corner linked $\mathrm{MO}_{4}$ tetrahedra (blue) and $\mathrm{AO}_{6}$ trigonal metaprisms (green)) with the remaining $\mathrm{A}_{6} \mathrm{O}_{2}$ unit within the "channels" of this framework (A green spheres, $\mathrm{O}$ red spheres). incorporation, ${ }^{33}$ and we have been extending this work to examine the ability of the silicate apatites to accommodate water. These initial studies suggested low levels of water incorporation in cation stoichiometric apatite silicates, e.g. $\mathrm{La}_{8+x} \mathrm{~A}_{2-x} \mathrm{Si}_{6} \mathrm{O}_{26+x / 2}(\mathrm{~A}=\mathrm{Ca}, \mathrm{Sr}, \mathrm{Ba})$, while higher levels were observed in systems which contain oxygen excess and cation vacancies, i.e. $\mathrm{La}_{9.33+x} \mathrm{Si}_{6} \mathrm{O}_{26+3 x / 2}$. This initial work suggested, in particular, that for $x>0.17$ significant $(>0.5 \mathrm{O}$ per formula unit) water incorporation was observed. In this paper, we report a neutron diffraction and solid state NMR study examining the effect of such water incorporation in the two systems, $\mathrm{La}_{8} \mathrm{Sr}_{2} \mathrm{Si}_{6} \mathrm{O}_{26}$ and $\mathrm{La}_{9.6} \mathrm{Si}_{6} \mathrm{O}_{26.4}$. In particular, we have analyzed the effect of water incorporation on the structure, and the location of the interstitial oxide ion site.

\section{Experimental}

$\mathrm{La}_{9.6} \mathrm{Si}_{6} \mathrm{O}_{26.4}$ and $\mathrm{La}_{8} \mathrm{Sr}_{2} \mathrm{Si}_{6} \mathrm{O}_{26}$ were prepared as follows. High purity $\mathrm{La}_{2} \mathrm{O}_{3}, \mathrm{SrCO}_{3}$ and $\mathrm{SiO}_{2}$ were ground together in the correct stoichiometric ratio and heated for 12 hours at $1350{ }^{\circ} \mathrm{C}$, with a second firing at $1350{ }^{\circ} \mathrm{C}-1400{ }^{\circ} \mathrm{C}$ for a further 12 hours. Between firings the sample was reground to ensure a homogeneous mixture. Phase purity was established through X-ray powder diffraction (Bruker D8 diffractometer with $\mathrm{Cu} \mathrm{K}_{\alpha 1}$ radiation $=1.5406 \AA$ ).

For the water incorporation, half of each sample was heated in water in a hydrothermal vessel (model 4749 Parr digestion vessel with $23 \mathrm{ml}$ capacity) at $200{ }^{\circ} \mathrm{C}$ for 48 hours, as described previously. $^{33}$ The water contents were assessed through thermogravimetric analysis (Netzsch STA 449 F1 Jupiter Thermal Analyser). The TGA experiments were carried out in $\mathrm{N}_{2}$ with a heating rate of $10^{\circ} \mathrm{C} \min ^{-1}$ up to $700{ }^{\circ} \mathrm{C}$.

In order to gain additional information on the thermal stability of the water in the apatite structure, the hydrated $\mathrm{La}_{9.6} \mathrm{Si}_{6} \mathrm{O}_{26.4}$ sample was investigated further through high temperature X-ray diffraction, utilising a Bruker D8 diffractometer. Measurements were made between 50 and $550{ }^{\circ} \mathrm{C}$ in air.

The structures of both as prepared and hydrated $\mathrm{La}_{9.6} \mathrm{Si}_{6} \mathrm{O}_{26.4}$ and $\mathrm{La}_{8} \mathrm{Sr}_{2} \mathrm{Si}_{6} \mathrm{O}_{26}$ samples were determined by Rietveld refinement using neutron diffraction data. Room temperature data for as prepared $\mathrm{La}_{9.6} \mathrm{Si}_{6} \mathrm{O}_{26.4}$ and $\mathrm{La}_{8} \mathrm{Sr}_{2} \mathrm{Si}_{6} \mathrm{O}_{26}$, and hydrated $\mathrm{La}_{9.6} \mathrm{Si}_{6} \mathrm{O}_{26.4}$ samples were collected on diffractometer HRPT at the SINQ, Paul Scherrer Institut while room temperature data for hydrated $\mathrm{La}_{8} \mathrm{Sr}_{2} \mathrm{Si}_{6} \mathrm{O}_{26}$ were collected on the HRPD diffractometer, ISIS, Rutherford Appleton Laboratory. All structural refinements employed the GSAS suite of Rietveld refinement software. ${ }^{61}$

All ${ }^{29} \mathrm{Si}$ MAS and CPMAS NMR measurements were performed at an external $B_{0}$ field of 9.4 $\mathrm{T}$ using a Bruker DSX-400 spectrometer operating at a ${ }^{29} \mathrm{Si}$ Larmor frequency of 59.61 MHz. Each MAS and CPMAS NMR experiment was undertaken using a Bruker $4 \mathrm{~mm}$ dual channel (HX) MAS probe in which MAS frequencies $\left(\nu_{\mathrm{r}}\right)$ of $12 \mathrm{kHz}$ were achieved. The ${ }^{29} \mathrm{Si}$ pulse time calibration was performed on a sample of 
solid kaolinite where a $\pi / 2$ pulse width of $4 \mu \mathrm{s}$ was measured, and the reported ${ }^{29} \mathrm{Si}$ MAS NMR data were acquired using single pulse (Bloch decay) experiments with high power ${ }^{1} \mathrm{H}$ decoupling $\left(B_{1}=50 \mathrm{kHz}\right)$ during acquisition. A $\pi / 4$ excitation pulse of $2 \mu \mathrm{s}$ and a recycle delay of $30 \mathrm{~s}$ were common to all measurements and provided a quantitative description of the Si speciation, although checks with longer recycle delays of up to $120 \mathrm{~s}$ were also undertaken. For the ${ }^{29} \mathrm{Si}$ CPMAS measurements an initial ${ }^{1} \mathrm{H} \pi / 2$ time of $4 \mu$ s and a Hartmann-Hahn contact period of $5 \mathrm{~ms}$ were also calibrated on the kaolinite sample, with a recycle delay of $5 \mathrm{~s}$ being used. All ${ }^{29} \mathrm{Si}$ chemical shifts are reported against the primary TMS solution reference $\left(\begin{array}{lll}\delta & 0.0 & \mathrm{ppm}\end{array}\right)$ via the secondary kaolinite solid reference $(\delta-92.0 \mathrm{ppm})$.

The corresponding ${ }^{17} \mathrm{O}$ and ${ }^{1} \mathrm{H}$ MAS NMR measurements were performed on ${ }^{17} \mathrm{O}$ enriched samples at an external $B_{0}$ field of 14.1 T using a Bruker Avance II-600 spectrometer operating at ${ }^{17} \mathrm{O}$ and ${ }^{1} \mathrm{H}$ Larmor frequencies of 81.30 and $600.13 \mathrm{MHz}$, respectively. Since, the natural abundance of ${ }^{17} \mathrm{O}$ is very low, it is important to enrich the samples prior to measurement of the ${ }^{17} \mathrm{O}$ NMR. To achieve ${ }^{17} \mathrm{O}$ enrichment, the samples (1 g) were initially hydrated $\left(0.5 \mathrm{~cm}^{3} \quad 90 \%{ }^{17} \mathrm{O}\right.$ enriched water) under hydrothermal conditions $\left(200{ }^{\circ} \mathrm{C}\right.$, 48 hours) as described earlier. These ${ }^{17} \mathrm{O}$ MAS NMR experiments were undertaken using a Bruker $2.5 \mathrm{~mm}$ triple channel (HXY) MAS probe in which MAS frequencies $\left(\nu_{\mathrm{r}}\right)$ of $31.25 \mathrm{kHz}$ were achieved. The ${ }^{17} \mathrm{O}$ pulse time calibration was performed on a water sample where a 'non-selective' (solution) $\pi / 2$ pulse width of $3 \mu$ s was measured, and the reported ${ }^{17} \mathrm{O}$ MAS NMR data were acquired using a rotor synchronized spin echo $(\theta-$ $\tau-2 \theta-\tau-$ acq.) experiment. The 'selective' (solids) pulses used $\theta$ and $2 \theta$ pulses of 1 and $2 \mu$ s duration (representing flip angles of $\pi / 2$ and $\pi$ ), respectively, and a recycle delay of $10 \mathrm{~s}$ was employed. All ${ }^{17} \mathrm{O}$ chemical shifts are reported against the primary solution reference of water $(\delta 0.0 \mathrm{ppm})$. The ${ }^{1} \mathrm{H}$ pulse time calibration was performed on a water sample where a $\pi / 2$ pulse width of $3 \mu$ s was measured, and the reported ${ }^{1} \mathrm{H}$ MAS
NMR data were acquired using a rotor synchronized spin echo $\left(\theta-\tau-2 \theta-\tau-\right.$ acq.) experiment. All reported ${ }^{1} \mathrm{H}$ chemical shifts are referenced to the TMS primary reference $(\delta 0.0 \mathrm{ppm})$.

\section{Results and discussion}

\subsection{As prepared and hydrated $\mathrm{La}_{8} \mathrm{Sr}_{2} \mathrm{Si}_{6} \mathrm{O}_{26}$}

In the case of as-prepared $\mathrm{La}_{8} \mathrm{Sr}_{2} \mathrm{Si}_{6} \mathrm{O}_{26}$, the sample should nominally have no oxygen excess, and therefore negligible interstitial oxide ion content. In agreement with this, the neutron diffraction structural study found no evidence for any interstitial oxide ions, along with a low thermal displacement parameter for the channel oxide ion site. The final refined structural parameters (space group $P 6_{3} / m$ was used in line with prior single crystal structural studies of the related $\mathrm{Nd}_{8} \mathrm{Sr}_{2} \mathrm{Si}_{6} \mathrm{O}_{26}$ system ${ }^{60}$ ) and bond distances are given in Tables 1 and 2, while the observed calculated and difference profiles are given in Fig. 2.

On hydration, a small expansion in the cell volume was observed, and TGA studies indicated a water content of 0.18 molecules per formula unit. The presence of water means the occupancy of interstitial sites by the extra oxide ions from the water. The neutron diffraction structural studies were in agreement with this, indicating the presence of interstitial oxide ions at a position of $(-0.0247,0.1416,0.6617)$. It was not possible to locate the proton site, most likely due to the low occupancy, thermal motion of these protons, and the presence of a range of different $\mathrm{H}$ sites with significant local displacement in these positions. The final refined structural parameters and bond distances are given in Tables 3 and 4, while the observed calculated and difference profiles are given in Fig. 3.

Accompanying the water incorporation, there was a small decrease in the $\mathrm{AO}_{6}$ metaprism twist angle from 23.23 to $23.20^{\circ}$, leading to a small expansion of the channels to accommodate this water.

Table 1 Structural parameters of as prepared $\mathrm{La}_{8} \mathrm{Sr}_{2} \mathrm{Si}_{6} \mathrm{O}_{26}$

\begin{tabular}{|c|c|c|c|c|c|c|}
\hline Space group & & $a / b(\AA)$ & $c(\AA)$ & $R_{\mathrm{wp}}$ & $R_{\mathrm{p}}$ & $\chi^{2}$ \\
\hline $\mathrm{P6}_{3} / \mathrm{m}$ & & $9.70680(8)$ & $7.23791(7)$ & 2.54 & 1.92 & 5.884 \\
\hline $\mathrm{La}(1)$ & $2 b$ & $1 / 3$ & $2 / 3$ & $-0.0006(2)$ & $0.597(20)$ & 0.5 \\
\hline $\operatorname{Sr}(1)$ & $2 \mathrm{~b}$ & $1 / 3$ & $2 / 3$ & $-0.0006(2)$ & $0.597(20)$ & 0.5 \\
\hline $\mathrm{La}(2)$ & $2 b$ & $0.01292(11)$ & $0.24500(9)$ & $1 / 4$ & $0.436(15)$ & 1 \\
\hline $\mathrm{O}(2)$ & $6 c$ & $0.59401(13)$ & $0.47124(15)$ & $1 / 4$ & & 1 \\
\hline $\mathrm{O}(3)$ & $6 c$ & $0.34263(11)$ & $0.25364(10)$ & $0.07024(11)$ & & 1 \\
\hline $\mathrm{O}(4)$ & $2 \mathrm{a}$ & 0 & 0 & $1 / 4$ & & 1 \\
\hline $100 \times$ & $U_{11}$ & $U_{22}$ & $U_{33}$ & $U_{12}$ & $U_{13}$ & $U_{23}$ \\
\hline $\mathrm{O}(1)$ & $1.40(6)$ & $1.04(6)$ & $0.867(67)$ & $1.049(56)$ & 0 & 0 \\
\hline $\mathrm{O}(2)$ & $0.43(6)$ & $0.42(5)$ & $1.229(58)$ & $0.116(50)$ & 0 & 0 \\
\hline $\mathrm{O}(3)$ & $2.02(5)$ & $0.77(4)$ & $0.552(34)$ & $0.739(38)$ & $-0.573(33)$ & $-0.287(30)$ \\
\hline
\end{tabular}


Table 2 Selected bond distances for as prepared $\mathrm{La}_{8} \mathrm{Sr}_{2} \mathrm{Si}_{6} \mathrm{O}_{26}$

\begin{tabular}{ll}
\hline Bond & Bond distance $(\AA)$ \\
\hline $\mathrm{La}(1) / \mathrm{Sr}(1)-\mathrm{O}(1)$ & $2.5048(12), 2.5045(12), 2.5041(12)$ \\
$\mathrm{La}(1) / \mathrm{Sr}(1)-\mathrm{O}(2)$ & $2.5474(12), 2.5480(12), 2.5475(12)$ \\
$\mathrm{La}(1) / \mathrm{Sr}(1)-\mathrm{O}(3)$ & $2.8835(10), 2.8825(10), 2.8832(10)$ \\
$\mathrm{La}(2)-\mathrm{O}(1)$ & $2.7204(15)$ \\
$\mathrm{La}(2)-\mathrm{O}(2)$ & $2.4970(15)$ \\
$\mathrm{La}(2)-\mathrm{O}(3)(\times 2)$ & $2.4731(8)$ \\
$\mathrm{La}(2)-\mathrm{O}(3)(\times 2)$ & $2.6005(12)$ \\
$\mathrm{La}(2)-\mathrm{O}(4)$ & $2.3180(7)$ \\
$\mathrm{Si}(1)-\mathrm{O}(1)$ & $1.6222(18)$ \\
$\mathrm{Si}(1)-\mathrm{O}(2)$ & $1.6236(18)$ \\
$\mathrm{Si}(1)-\mathrm{O}(3)(\times 2)$ & $1.6302(11)$ \\
&
\end{tabular}

\subsection{As prepared $\mathrm{La}_{9.6} \mathrm{Si}_{6} \mathrm{O}_{26.4}$}

Among the various space groups reported to be exhibited by apatite systems containing cation vacancies/oxygen excess, ${ }^{16}$ space groups $P 6_{3}$ and $P \overline{3}$ were analysed initially, as these are the most widely reported space groups used to describe oxygen excess apatite-type silicates. ${ }^{17}$ The initial structural refinement using both symmetries showed similar $R$-factor values, and thus the higher symmetry space group $P 6_{3}$ was chosen for the full structural refinement. Since there is no special position in terms of the $\mathrm{z}$ coordinate in this space group, it was required to constrain the $z$ coordinate of the channel oxygen to a value of $1 / 4$ to provide a fixed origin in $z$. In the initial structure refinement, there was no evidence of any cation vacancy ordering phenomena involving the $\mathrm{La}(1)$ and $\mathrm{La}(2)$ sites, ${ }^{18}$ and so to avoid errors involving the high degree of correlation between these sites, their fractional occupancy and atomic displacement parameters were constrained to be equal. Among the various interstitial oxide ion sites reported in apatite silicates, two sites at channel periphery $(0.037,0.277,0.584)^{17}$ and near channel centre $(0.018,0.050,0.573)^{12}$ were tested initially. The refinement for both sites showed an improved fit compared to the model without any interstitial oxide ion $\left(R_{\mathrm{wp}}=2.18\right)$ but the interstitial oxide ion positioned near the channel centre resulted in a small improvement in fit $\left(R_{\mathrm{wp}}=2.08\right)$ over the channel periphery site $\left(R_{\mathrm{wp}}=2.13\right)$. Considering both models have the same number of variables, the full structural refinement was continued therefore with the interstitial oxide ion near the channel centre, although the fact that the difference in the two models is relatively small may indicate that there are a range of interstitial oxide ion positions, with a greater occupancy of sites closer to the channel centre than the periphery.

The structural parameters and bond distances for the as prepared $\mathrm{La}_{9.6} \mathrm{Si}_{6} \mathrm{O}_{26.4}$ sample using neutron diffraction data are given Table 5 and 6 , with the observed, calculated and difference profiles in Fig. 4. The data indicated a refined composition of $\mathrm{La}_{9.50} \mathrm{Si}_{6} \mathrm{O}_{26.26}$, close to that expected from the starting stoichiometry. The position of the interstititial oxide ions is similar to the position observed by Bechade et al. and others. ${ }^{38,44,45}$ Furthermore, as in the prior studies, the presence of oxide ion interstitials is accompanied by some vacancies in the ideal channel oxide ion site. In their work, Bechade et al. proposed a defect complex $\left(\mathrm{O}^{\prime \prime}{ }_{\mathrm{i}}-\mathrm{V}_{\mathrm{O}}^{*}-\mathrm{O}^{\prime \prime}{ }_{\mathrm{i}}\right.$ (Kröger-Vink notation,

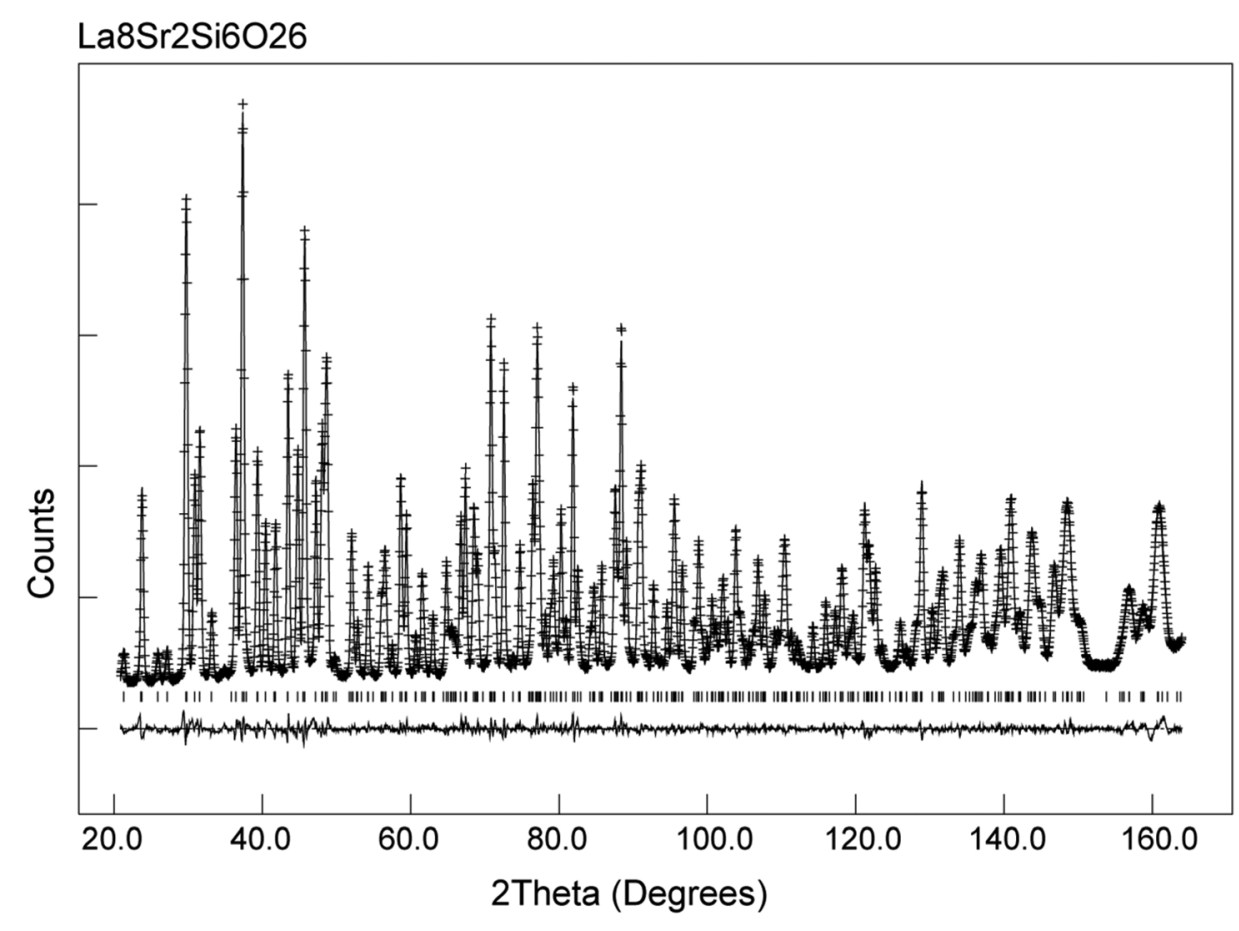

Fig. 2 Observed, calculated and difference neutron diffraction profiles for as-prepared $\mathrm{La}_{8} \mathrm{Sr}_{2} \mathrm{Si}_{6} \mathrm{O}_{26}$. 
Table 3 Structural parameters of hydrated $\mathrm{La}_{8} \mathrm{Sr}_{2} \mathrm{Si}_{6} \mathrm{O}_{26}$

\begin{tabular}{|c|c|c|c|c|c|c|}
\hline Space group & & $a / b(\AA)$ & $c(\AA)$ & $R_{\mathrm{wp}}$ & $R_{\mathrm{p}}$ & $\chi^{2}$ \\
\hline $\mathrm{P6}_{3} / \mathrm{m}$ & & $9.72828(11)$ & $7.25273(9)$ & 1.58 & 2.23 & 7.773 \\
\hline $\mathrm{La}(1)$ & $2 b$ & $1 / 3$ & $2 / 3$ & $-0.0009(1)$ & $0.531(16)$ & 0.5 \\
\hline $\operatorname{Sr}(1)$ & $2 b$ & $1 / 3$ & $2 / 3$ & $-0.0009(1)$ & $0.531(16)$ & 0.5 \\
\hline $\mathrm{La}(2)$ & $2 b$ & $0.01320(9)$ & $0.24494(8)$ & $1 / 4$ & $0.454(12)$ & 1 \\
\hline $\mathrm{O}(2)$ & $6 c$ & $0.59393(11)$ & $0.4711(3)$ & $1 / 4$ & & 1 \\
\hline $\mathrm{O}(3)$ & $6 c$ & $0.34321(9)$ & $0.2541(1)$ & $0.07047(8)$ & & 1 \\
\hline $\mathrm{O}(4)$ & $2 \mathrm{a}$ & 0 & 0 & $1 / 4$ & & $0.981(6)$ \\
\hline $\mathrm{O}(\mathrm{i})$ & $6 c$ & $-0.0246(33)$ & $0.1416(32)$ & $0.6617(35)$ & & $0.031(2)$ \\
\hline $100 \times$ & $U_{11}$ & $U_{22}$ & $U_{33}$ & $U_{12}$ & $U_{13}$ & $U_{23}$ \\
\hline $\mathrm{O}(1)$ & $1.49(5)$ & $1.11(6)$ & $0.496(47)$ & $1.084(49)$ & 0 & 0 \\
\hline $\mathrm{O}(2)$ & $0.24(5)$ & $0.37(4)$ & $1.260(57)$ & $-0.001(41)$ & 0 & 0 \\
\hline
\end{tabular}

Table 4 Selected bond distances for hydrated $\mathrm{La}_{8} \mathrm{Sr}_{2} \mathrm{Si}_{6} \mathrm{O}_{26}$

\begin{tabular}{ll}
\hline Bond & Bond distance $(\AA)$ \\
\hline $\mathrm{La}(1) / \mathrm{Sr}(1)-\mathrm{O}(1)$ & $2.5111(13), 2.5108(13), 2.5105(13)$ \\
$\mathrm{La}(1) / \mathrm{Sr}(1)-\mathrm{O}(2)$ & $2.5519(13), 2.5525(13), 2.5520(13)$ \\
$\mathrm{La}(1) / \mathrm{Sr}(1)-\mathrm{O}(3)$ & $2.8876(11), 2.8866(11), 2.8873(11)$ \\
$\mathrm{La}(2)-\mathrm{O}(1)$ & $2.7233(17)$ \\
$\mathrm{La}(2)-\mathrm{O}(2)$ & $2.5078(16)$ \\
$\mathrm{La}(2)-\mathrm{O}(3)(\times 2)$ & $2.4810(9)$ \\
$\mathrm{La}(2)-\mathrm{O}(3)(\times 2)$ & $2.6081(13)$ \\
$\mathrm{La}(2)-\mathrm{O}(4)$ & $2.3202(8)$ \\
$\mathrm{La}(2)-\mathrm{O}(\mathrm{i})$ & $2.40(4), 1.843(34), 2.40(4)$ \\
$\mathrm{Si}(1)-\mathrm{O}(1)$ & $1.6207(20)$ \\
$\mathrm{Si}(1)-\mathrm{O}(2)$ & $1.6258(21)$ \\
$\mathrm{Si}(1)-\mathrm{O}(3)(\times 2)$ & $1.6331(13)$ \\
$\mathrm{Si}(1)-\mathrm{O}(\mathrm{i})(\times 2)$ & $2.24(4)$ \\
&
\end{tabular}

$\mathrm{O}^{\prime \prime}{ }_{i}=$ interstitial oxide ion with a double effective negative charge, $\mathrm{V}_{\mathrm{O}}^{\prime \prime}=$ oxide ion vacancy with a double effective positive charge)), and in the present study, a similar complex can be proposed. The observed length scale in this study for this complex is $2.27 \AA$ which is smaller than the predicted value of $2.93 \AA$ from the modelling work. ${ }^{10}$ However, it should be noted that the atomic displacement parameter for $\mathrm{O}(6)$ is very high perpendicular to the channel $\left(100 \times U_{22}=34 \AA^{2}\right)$. This suggests significant local displacement from the refined position, which may hence allow an increase in the $\mathrm{O}^{\prime \prime}{ }_{i}^{-} \mathrm{V}_{\mathrm{O}}$. length. Overall it would suggest the presence of various interstitial oxide ion sites with differing displacements from the channel centre. In particular, the anisotropic thermal ellipsoids for the $\mathrm{O}(6)$ sites are directed towards channel lanthanum, $\mathrm{La}(3)$ (Fig. 5), which is not unexpected as $\mathrm{O}(6)$ is highly underbonded (bond valence sum calculations for this oxygen site give a value of only -1.08), and so some local displacement might be expected to aid the stability of this oxide ion site.

\subsection{Hydrated $\mathrm{La}_{9.6} \mathrm{Si}_{6} \mathrm{O}_{26.4}$}

The structural parameters and bond distances for hydrated $\mathrm{La}_{9.6} \mathrm{Si}_{6} \mathrm{O}_{26.4}$ are given in Tables 7 and 8 with the observed, calculated and difference profiles in Fig. 6 . It was not possible to locate the proton site, most likely due to the presence of a range of different $\mathrm{H}$ sites, thermal motion of the $\mathrm{H}$, and significant local displacement in these positions. In this respect, further studies at low temperature $(\approx 4 \mathrm{~K})$ would be required, as has been performed to locate the proton sites in perovskite systems. The data indicated a refined composition of $\mathrm{La}_{9.53} \mathrm{Si}_{6} \mathrm{O}_{26.98}$ (excluding protons) showing a significant increase in the $\mathrm{O}$ content. If we assume that this extra $\mathrm{O}$ is charge balanced by protons, the composition of $\mathrm{La}_{9.53} \mathrm{Si}_{6} \mathrm{O}_{26.98} \mathrm{H}_{1.37} \quad\left(\mathrm{La}_{9.53} \mathrm{Si}_{6} \mathrm{O}_{26.295} \cdot 0.685 \mathrm{H}_{2} \mathrm{O}\right)$ is obtained. Apart from the increased $\mathrm{O}$ content, the major difference compared to the as prepared sample is the significant deviation of the interstitial oxide ion site away from the channel centre (0.133, 0.143, 0.419) (Fig. 7). It can be proposed that the additional displacement from the channel centre is required to accommodate more anions in the structure, and the data showed that further structure distortion accompanied the water incorporation. In particular, the calculated average metaprism twist angle of $\mathrm{LaO}_{6}$ was decreased from $22.24^{\circ}$ to $21.68^{\circ}$, in order to expand the channel size to allow the accommodation of the extra oxide ions, resulting in a significant increase $(0.70 \%)$ in the cell size along $a / b$ and decrease $(0.17 \%)$ in $c$. These cell parameter changes can be elegantly demonstrated using high temperature X-ray diffraction data (see Fig. 8). Such data show that there is a steep decrease in the size of $a / b$ and increase in $\mathrm{c}$ at around $210{ }^{\circ} \mathrm{C}$, on heating the hydrated sample (due to water loss), while the as prepared sample showed a linear increase over the temperature range. This single stage dehydration process can also be easily noticed on the plot of cell volume change with temperature. 


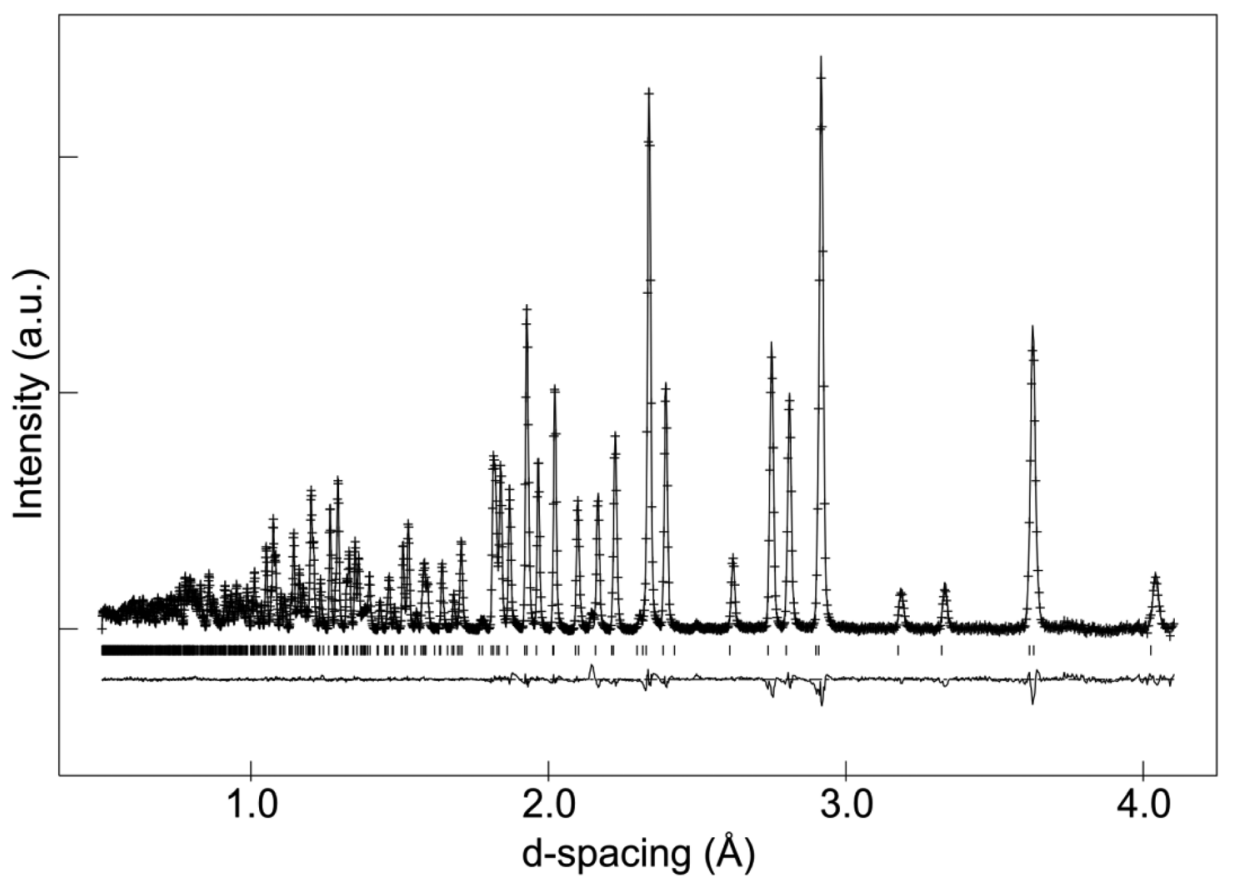

Fig. 3 Observed, calculated and difference neutron diffraction profiles for hydrated $\mathrm{La}_{8} \mathrm{Sr}_{2} \mathrm{Si}_{6} \mathrm{O}_{26}$.

Table 5 Structural parameters of as prepared $\mathrm{La}_{9.6} \mathrm{Si}_{6} \mathrm{O}_{26.4}$

\begin{tabular}{|c|c|c|c|c|c|c|}
\hline Space group & & $a / b(\AA)$ & $c(\AA)$ & $R_{\mathrm{wp}}$ & $R_{\mathrm{p}}$ & $\chi^{2}$ \\
\hline$P 6_{3}$ & & $9.72441(4)$ & $7.18726(5)$ & 2.00 & 1.58 & 3.299 \\
\hline $\mathrm{La}(1)$ & $2 b$ & $1 / 3$ & $2 / 3$ & $-0.0161(5)$ & $1.28(2)$ & $0.874(2)$ \\
\hline $\mathrm{La}(2)$ & $2 b$ & $2 / 3$ & $1 / 3$ & $-0.0139(5)$ & $1.28(2)$ & $0.874(2)$ \\
\hline $\mathrm{La}(3)$ & $6 c$ & $0.2286(1)$ & $-0.0119(1)$ & $0.2427(5)$ & $1.09(1)$ & 1 \\
\hline $\mathrm{O}(2)$ & $6 c$ & $0.5948(1)$ & $0.4729(2)$ & $0.2438(10)$ & & 1 \\
\hline $\mathrm{O}(3)$ & $6 c$ & $0.3531(4)$ & $0.2580(5)$ & $0.0592(8)$ & & 1 \\
\hline $\mathrm{O}(4)$ & $6 c$ & $0.6643(6)$ & $0.7466(5)$ & $0.9204(7)$ & & 1 \\
\hline $\mathrm{O}(5)$ & $2 \mathrm{a}$ & 0 & 0 & $1 / 4$ & & $0.853(5)$ \\
\hline $\mathrm{O}(\mathrm{i})$ & $6 c$ & $0.0033(23)$ & $0.0193(41)$ & $0.4049(21)$ & & $0.092(3)$ \\
\hline $100 \times$ & $U_{11}$ & $U_{22}$ & $U_{33}$ & $U_{12}$ & $U_{13}$ & $U_{23}$ \\
\hline $\mathrm{O}(\mathrm{i})$ & $8.9(18)$ & $33.8(36)$ & $8.3(15)$ & $13.7(24)$ & $15.0(16)$ & $19.3(24)$ \\
\hline
\end{tabular}

The water content of the hydrated sample was determined by TGA measurements (see Fig. 9). Unlike the single stage dehydration suggested by the high temperature X-ray diffraction data, there was evidence for a two stage water loss from the TGA data: firstly there was an abrupt loss in mass at around $280{ }^{\circ} \mathrm{C}$ with a second mass loss at around $470{ }^{\circ} \mathrm{C}$. Since high temperature X-ray diffraction data did not show any change at higher temperature, the second mass loss was attributed to the decomposition of an impurity phase (most likely amorphous). As the structure refinement indicated a lower La content than the starting ratio, it was presumed that this may be amorphous $\mathrm{La}(\mathrm{OH})_{3} \cdot \mathrm{La}(\mathrm{OH})_{3}$ is known to decompose in two steps, via an $\mathrm{LaOOH}$ intermediate as outlined below, and so it was proposed that the second mass loss observed in the 
Table 6 Selected bond distances for as prepared $\mathrm{La}_{9.6} \mathrm{Si}_{6} \mathrm{O}_{26.4}$

\begin{tabular}{ll}
\hline Bond & Bond distance $(\AA)$ \\
\hline $\mathrm{Si}-\mathrm{O}(1)$ & $1.620(1)$ \\
$\mathrm{Si}-\mathrm{O}(2)$ & $1.618(1)$ \\
$\mathrm{Si}-\mathrm{O}(3)$ & $1.674(1)$ \\
$\mathrm{Si}-\mathrm{O}(4)$ & $1.587(1)$ \\
$\mathrm{La}(1)-\mathrm{O}(1)(\times 3)$ & $2.535(1)$ \\
$\mathrm{La}(1)-\mathrm{O}(2)(\times 3)$ & $2.503(1)$ \\
$\mathrm{La}(1)-\mathrm{O}(4)(\times 3)$ & $2.944(1)$ \\
$\mathrm{La}(2)-\mathrm{O}(1)(\times 3)$ & $2.453(1)$ \\
$\mathrm{La}(2)-\mathrm{O}(2)(\times 3)$ & $2.591(1)$ \\
$\mathrm{La}(2)-\mathrm{O}(3)(\times 3)$ & $2.806(1)$ \\
$\mathrm{La}(3)-\mathrm{O}(1)$ & $2.762(1)$ \\
$\mathrm{La}(3)-\mathrm{O}(2)$ & $2.519(1)$ \\
$\mathrm{La}(3)-\mathrm{O}(3)$ & $2.630(1), 2.476(1)$ \\
$\mathrm{La}(3)-\mathrm{O}(4)$ & $2.464(1), 2.586(1)$ \\
$\mathrm{La}(3)-\mathrm{O}(5)$ & $2.284(1)$ \\
$\mathrm{O}(\mathrm{i})-\mathrm{La}(3)$ & $2.632(1), 2.677(1), 2.405(1)$
\end{tabular}

TGA plots was due to the LaOOH dehydrating. This would suggest that part of the first mass loss was due to $\mathrm{La}(\mathrm{OH})_{3}$ dehydrating to $\mathrm{LaOOH}$.

$$
2 \mathrm{La}(\mathrm{OH})_{3} \stackrel{280^{\circ} \mathrm{C}}{\longrightarrow} 2 \mathrm{LaOOH}+2 \mathrm{H}_{2} \mathrm{O} \uparrow \stackrel{470^{\circ} \mathrm{C}}{\longrightarrow} \mathrm{La}_{2} \mathrm{O}_{3}+\mathrm{H}_{2} \mathrm{O} \uparrow
$$

In order to estimate the contribution from this proposed amorphous $\mathrm{La}(\mathrm{OH})_{3}$ impurity phase, firstly, the mass of $\mathrm{LaOOH}$ was estimated from the mass loss at $470{ }^{\circ} \mathrm{C}$ and subsequently, the mass of $\mathrm{La}(\mathrm{OH})_{3}$ was calculated $(1.7(2) \mathrm{wt} \%)$. Eliminating the contribution of the above process, the calculated level of water incorporated was $0.75 \mathrm{H}_{2} \mathrm{O}$ per formula unit, which is similar to the composition $\mathrm{La}_{9.53} \mathrm{Si}_{6} \mathrm{O}_{26.295} \cdot 0.685 \mathrm{H}_{2} \mathrm{O}$ and the calculated interstitial content $(\approx 1 \mathrm{O}$ per formula unit) from the diffraction studies. The dehydration temperature difference between X-ray diffraction study and the TGA result is due to the fact that the TGA measurement was performed with a $10^{\circ} \mathrm{C} \mathrm{min}^{-1}$ ramp rate, and so the experiment is performed under non-equilibrium conditions.

\subsection{MAS NMR studies}

All ${ }^{29} \mathrm{Si}$ MAS and CPMAS NMR data acquired from the $\mathrm{La}_{8} \mathrm{Sr}_{2} \mathrm{Si}_{6} \mathrm{O}_{26}$ and $\mathrm{La}_{9.6} \mathrm{Si}_{6} \mathrm{O}_{26.4}$ systems are presented in Fig. 10 (a) and (b), respectively. The ${ }^{29} \mathrm{Si}$ MAS NMR data demonstrate that the $\mathrm{Si}$ speciation comprising the stoichiometric $\mathrm{La}_{8} \mathrm{Sr}_{2} \mathrm{Si}_{6} \mathrm{O}_{26}$ system is dominated by monomeric framework $\mathrm{SiO}_{4}$ environments which are influenced by $\mathrm{Sr}$ substitution on the La position; this is evidenced by broadening of the dominant ${ }^{29} \mathrm{Si}$ resonance at an isotropic chemical shift at $\delta_{\text {iso }}$ $-77.5 \mathrm{ppm}$. The much less intense resonances at $\delta_{\text {iso }} \sim-80.2$ and $-82.2 \mathrm{ppm}$ are ascribed to low levels of cation vacancies and interstitial species that originate from substitutional arrangements and charge balancing. In comparison, the multiple resonances from the ${ }^{29} \mathrm{Si}$ MAS NMR data describing the non-stoichiometric $\mathrm{La}_{9.6} \mathrm{Si}_{6} \mathrm{O}_{26.4}$ system reveal more complex $\mathrm{Si}$ speciation which emanates from the substantial influences of the much higher levels of cation vacancies and oxygen interstitials upon the local $\mathrm{SiO}_{4}$ environment. These observations mirror previously reported ${ }^{29} \mathrm{Si}$ MAS NMR studies. ${ }^{15,26}$ Similar to $\mathrm{La}_{8} \mathrm{Sr}_{2} \mathrm{Si}_{6} \mathrm{O}_{26}$, the $\mathrm{La}_{9.6} \mathrm{Si}_{6} \mathrm{O}_{26.4}$ system is characterised by a dominant resonance at $\delta_{\text {iso }}-78.4 \mathrm{ppm}$, however the pertur-

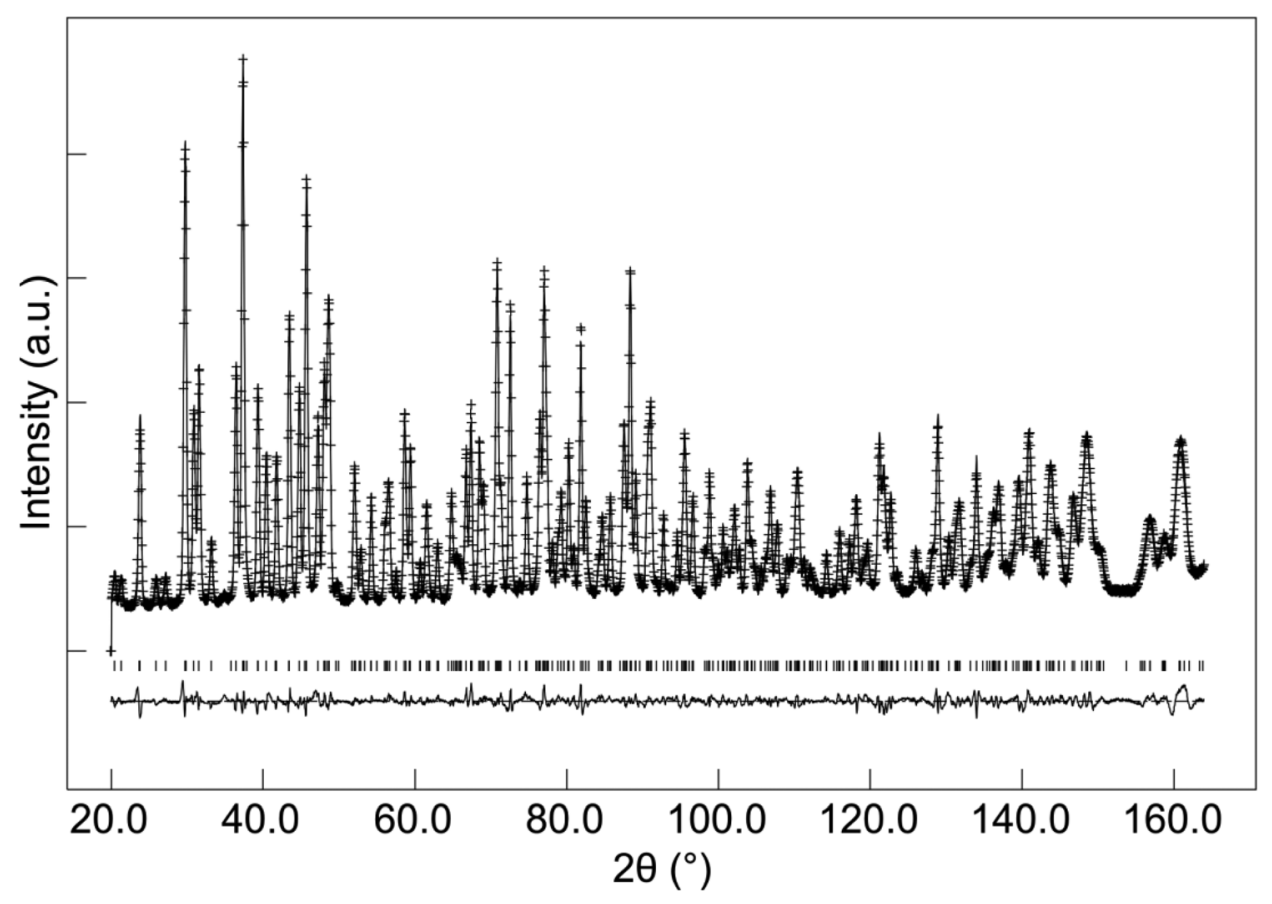

Fig. 4 Observed, calculated and difference neutron diffraction profiles for as-prepared $\mathrm{La}_{9.6} \mathrm{Si}_{6} \mathrm{O}_{26.4}$. 


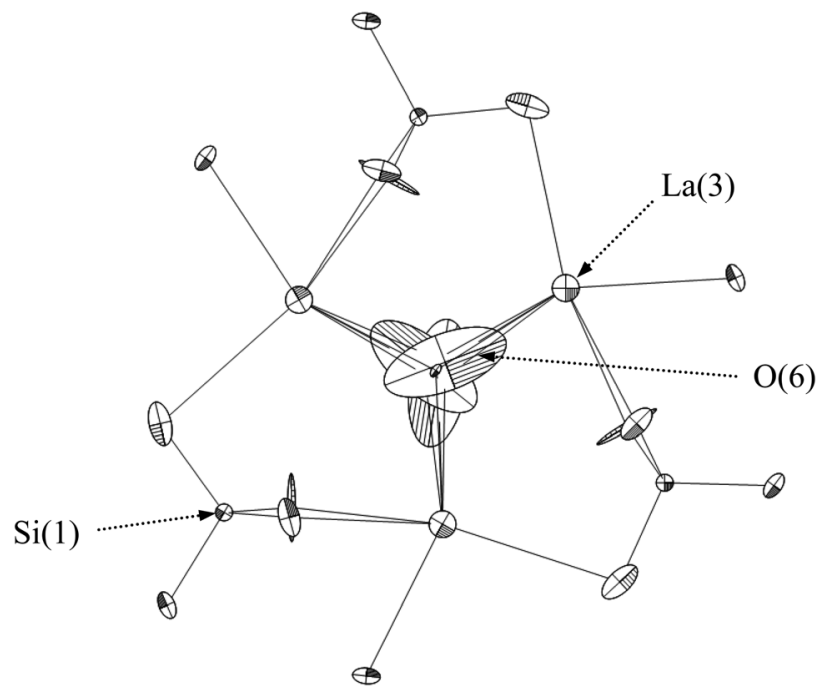

Fig. 5 The anisotropic thermal ellipsoids around the apatite channel position of as prepared $\mathrm{La}_{9.6} \mathrm{Si}_{6} \mathrm{O}_{26.4}$, viewed down the $c$-axis.

bations to the $\mathrm{SiO}_{4}$ framework are observed by the additional upfield resonances at $\delta_{\text {iso }}-80.5,-82.3,-84.6$ and $-86.0 \mathrm{ppm}$. This trend of upfield shifted resonances is consistent with the increased electronegativity influencing the immediate $\mathrm{Si}$ environment induced by $\mathrm{La}^{3+}$ cation vacancies immediately surrounding the $\mathrm{SiO}_{4}$ monomeric unit, coupled with an additional $\mathrm{O}$ coordination/proximity to the $\mathrm{SiO}_{4}$ site via the presence of $\mathrm{O}$ interstitials.

The ${ }^{29} \mathrm{Si}$ CPMAS NMR data shown in Fig. 10(b) contrast markedly with the corresponding MAS NMR data discussed above. It is immediately evident that the signal-to-noise of these CPMAS data is greatly inferior thus suggesting that, despite there being an abundance of $\mathrm{H}$ species (i.e. $\mathrm{OH}$ and $\mathrm{H}_{2} \mathrm{O}$ ) to facilitate ${ }^{1} \mathrm{H}^{-29} \mathrm{Si}$ cross-polarisation, the motion of the intercalated $\mathrm{OH} / \mathrm{H}_{2} \mathrm{O}$ modulates the ${ }^{1} \mathrm{H}^{2}{ }^{29} \mathrm{Si}$ dipolar interaction and greatly diminishes the efficiency of the Hartmann-Hahn condition. For both of the hydrated $\mathrm{La}_{8} \mathrm{Sr}_{2} \mathrm{Si}_{6} \mathrm{O}_{26}$ and $\mathrm{La}_{9.6} \mathrm{Si}_{6} \mathrm{O}_{26.4}$ systems only the monomeric $\mathrm{SiO}_{4}$ positions exhibit some observable intensity above the noise level, and this is probably facilitated by proximity to a component of immobile $\mathrm{OH}$ interstitial species. However, the dehydration of these systems shows that both the mobile and immobile $\mathrm{OH}$ and $\mathrm{H}_{2} \mathrm{O}$ species are largely removed, as evidenced by the absence of a ${ }^{29} \mathrm{Si}$ signal above the baseline noise.

From Fig. 10(c) the ${ }^{17} \mathrm{O}$ MAS NMR data shows that similar $\mathrm{O}$ speciation from both systems is observed. Each spectrum is dominated by ${ }^{17} \mathrm{O}$ resonances at an apparent shift of $\delta$ $\sim 180-200 \mathrm{ppm}$ that are attributed to $\mathrm{O}$ species associated with the framework $\mathrm{SiO}_{4}$ element. In addition, there are two additional signals attributed to interstitial species observed from these data; a clearly resolved ${ }^{17} \mathrm{O}$ resonance at $\delta$ $\sim 40-50 \mathrm{ppm}$, which may represent a Si-based $(\mathrm{Si}-\mathrm{O}-\mathrm{Si}$ or $\mathrm{Si}-$ $\mathrm{OH})$ interstitial O species bridging between $\mathrm{SiO}_{4}$ framework moieties, and a partially resolved shoulder at $\delta \sim 260-270 \mathrm{ppm}$ which is assigned to the less prevalent $\mathrm{Si}-\mathrm{O}-\mathrm{La}$ interstitial species. The latter assignment is consistent with the observation of interstitial $\mathrm{O}$ species in previously reported silicate- and germanate-based rare earth apatite SOFC materials. ${ }^{47,49}$ It can be observed that upon dehydration of these systems both of these interstitial species are essentially removed, with the more complete removal of the $\mathrm{Si}-\mathrm{O}-\mathrm{Si} / \mathrm{Si}-\mathrm{OH}$ interstitial species being observed from the $\mathrm{La}_{8} \mathrm{Sr}_{2} \mathrm{Si}_{6} \mathrm{O}_{26}$ system, suggesting that this component is mostly related to Si-OH (see Fig. 10(b)). Previous

Table 7 Structural parameters for hydrated $\mathrm{La}_{9.6} \mathrm{Si}_{6} \mathrm{O}_{26.4}$

\begin{tabular}{|c|c|c|c|c|c|c|}
\hline Space group & & $a / b(\AA)$ & $c(\AA)$ & $R_{\mathrm{wp}}$ & $R_{\mathrm{p}}$ & $\chi^{2}$ \\
\hline$P 6_{3}$ & & $9.79242(10)$ & 7.17565(9) & 2.47 & 1.93 & 5.309 \\
\hline $\mathrm{La}(1)$ & $2 b$ & $1 / 3$ & $2 / 3$ & $0.0058(9)$ & $1.93(4)$ & $0.882(3)$ \\
\hline $\mathrm{La}(2)$ & $2 \mathrm{~b}$ & $2 / 3$ & $1 / 3$ & $0.0028(9)$ & $1.93(4)$ & $0.882(3)$ \\
\hline $\mathrm{La}(3)$ & $6 c$ & $0.2360(1)$ & $-0.0077(2)$ & $0.2438(6)$ & $1.28(2)$ & 1 \\
\hline $\mathrm{O}(2)$ & $6 c$ & $0.5939(2)$ & $0.4724(3)$ & $0.2515(9)$ & & 1 \\
\hline $\mathrm{O}(3)$ & $6 c$ & $0.3624(4)$ & $0.2649(6)$ & $0.0628(6)$ & & 1 \\
\hline $\mathrm{O}(4)$ & $6 c$ & $0.6664(6)$ & $0.7494(6)$ & $0.9169(6)$ & & 1 \\
\hline $\mathrm{O}(5)$ & $2 \mathrm{a}$ & 0 & 0 & $1 / 4$ & & $0.890(11)$ \\
\hline $\mathrm{O}(\mathrm{i})$ & $6 c$ & $0.1334(20)$ & $0.1425(12)$ & $0.4192(17)$ & & $0.200(7)$ \\
\hline $100 \times$ & $U_{11}$ & $U_{22}$ & $U_{33}$ & $U_{12}$ & $U_{13}$ & $U_{23}$ \\
\hline $\mathrm{O}(\mathrm{i})$ & $8.5(13)$ & $0.20(58)$ & $3.09(71)$ & $3.07(66)$ & $0.52(70)$ & $-2.21(51)$ \\
\hline
\end{tabular}


Table 8 Selected bond distances for hydrated $\mathrm{La}_{9.6} \mathrm{Si}_{6} \mathrm{O}_{26.4}$

\begin{tabular}{ll}
\hline Bond & Bond distance $(\AA)$ \\
\hline $\mathrm{Si}-\mathrm{O}(1)$ & $1.609(1)$ \\
$\mathrm{Si}-\mathrm{O}(2)$ & $1.618(1)$ \\
$\mathrm{Si}-\mathrm{O}(3)$ & $1.628(1)$ \\
$\mathrm{Si}-\mathrm{O}(4)$ & $1.614(1)$ \\
$\mathrm{La}(1)-\mathrm{O}(1)(\times 3)$ & $2.455(1)$ \\
$\mathrm{La}(1)-\mathrm{O}(2)(\times 3)$ & $2.580(1)$ \\
$\mathrm{La}(1)-\mathrm{O}(4)(\times 3)$ & $3.010(1)$ \\
$\mathrm{La}(2)-\mathrm{O}(1)(\times 3)$ & $2.505(1)$ \\
$\mathrm{La}(2)-\mathrm{O}(2)(\times 3)$ & $2.552(1)$ \\
$\mathrm{La}(2)-\mathrm{O}(3)(\times 3)$ & $2.740(1)$ \\
$\mathrm{La}(3)-\mathrm{O}(1)$ & $2.830(1)$ \\
$\mathrm{La}(3)-\mathrm{O}(2)$ & $2.479(1)$ \\
$\mathrm{La}(3)-\mathrm{O}(3)$ & $2.651(1), 2.520(1)$ \\
$\mathrm{La}(3)-\mathrm{O}(4)$ & $2.483(1), 2.538(1)$ \\
$\mathrm{La}(3)-\mathrm{O}(5)$ & $2.350(1)$ \\
$\mathrm{O}(\mathrm{i})-\mathrm{La}(3)$ & $2.489(1), 2.302(1), 2.538(1)$
\end{tabular}

studies on the $\mathrm{La}_{8} \mathrm{Y}_{2} \mathrm{Ge}_{6} \mathrm{O}_{27}$ rare earth apatite phase has clearly shown that a resonance observed at $\delta \sim 580 \mathrm{ppm}$ is associated with $\mathrm{O}$ channel species; ${ }^{49}$ this channel species is not clearly evident in the silicate-based $\mathrm{La}_{8} \mathrm{Sr}_{2} \mathrm{Si}_{6} \mathrm{O}_{26}$ and $\mathrm{La}_{9.6} \mathrm{Si}_{6} \mathrm{O}_{26.4}$ systems under study here. In addition, the resonance at $\delta \sim 380-390 \mathrm{ppm}$ (marked with an asterisk) in Fig. 10(c) is identified as a ${ }^{17} \mathrm{O}$ background signal arising from the $\mathrm{ZrO}_{2}$ MAS rotor material.

Although nominal $\mathrm{O}$ interstitial species within the hydrated and dehydrated $\mathrm{La}_{8} \mathrm{Sr}_{2} \mathrm{Si}_{6} \mathrm{O}_{26}$ and $\mathrm{La}_{9.6} \mathrm{Si}_{6} \mathrm{O}_{26.4}$ phases are indicated by ${ }^{17} \mathrm{O}$ resonances at $\delta \sim 40-50 \mathrm{ppm}$, a more precise identification of these species is afforded by the accompanying ${ }^{1} \mathrm{H}$ MAS NMR data shown in Fig. 10(d).
A substantial proportion of these interstitials are hydroxylated or $-\mathrm{Si}-\mathrm{OH}$ species as suggested by the narrow ${ }^{1} \mathrm{H}$ resonance at $\delta 1.0 \mathrm{ppm}$. The near-complete elimination of these species upon dehydration of the $\mathrm{La}_{8} \mathrm{Sr}_{2} \mathrm{Si}_{6} \mathrm{O}_{26}$ system, coupled with their partial removal upon dehydration of the $\mathrm{La}_{9.6} \mathrm{Si}_{6} \mathrm{O}_{26.4}$ system is demonstrated by the concomitant reduction of the $\delta \sim 40-50 \mathrm{ppm}$ resonance(s) in the ${ }^{17} \mathrm{O}$ MAS NMR data (see Fig. 9(c)) and the $\delta 1.0 \mathrm{ppm}$ resonance in the ${ }^{1} \mathrm{H}$ MAS NMR data (see Fig. 10(d)). The resonance at $\delta \sim 8 \mathrm{ppm}$ represents $\mathrm{H}$-bonded $\mathrm{OH}$ species residing in more occluded and sterically crowded environments; these are characterized by the larger downfield shift caused by the deshielding of the $\mathrm{H}$-bonding arrangement and a broader residual linewidth induced by a much larger homonuclear ${ }^{1} \mathrm{H}^{-1} \mathrm{H}$ dipolar interaction. In addition, the smaller resonances at $\delta 3.9$ and $4.9 \mathrm{ppm}$ represent different $\mathrm{H}_{2} \mathrm{O}$ environments within each unit cell. These resonances are also affected by the dehydration process.

These results demonstrate that the ${ }^{17} \mathrm{O}$ enrichment via heterogeneous gas phase exchange under autoclave conditions facilitates the exchange of the $\mathrm{O}$ positions comprising the $\mathrm{SiO}_{4}$ groups in both the as-synthesized $\mathrm{La}_{8} \mathrm{Sr}_{2} \mathrm{Si}_{6} \mathrm{O}_{26}$ and $\mathrm{La}_{9.6} \mathrm{Si}_{6} \mathrm{O}_{26.4}$ systems. These $\mathrm{O}$ exchange characteristics are similar to those reported for the analogous germanate systems. ${ }^{49}$ This work therefore suggests that while a direct interstitial oxide ion conduction mechanism may occur down the channels, as proposed by Bechade et al. ${ }^{38}$ there is likely to be significant contribution from exchange processes throughout the $\mathrm{SiO}_{4}$ tetrahedra network. In particular, such processes would explain the observation of significant conductivity perpendicular to the channel direction from single crystal studies. ${ }^{51}$

In comparison to the germanate $\left(\mathrm{La}_{10-x} \mathrm{Ge}_{6} \mathrm{O}_{27-3 x / 2}\right)$ apatite systems, there appears, however, to be less association of the

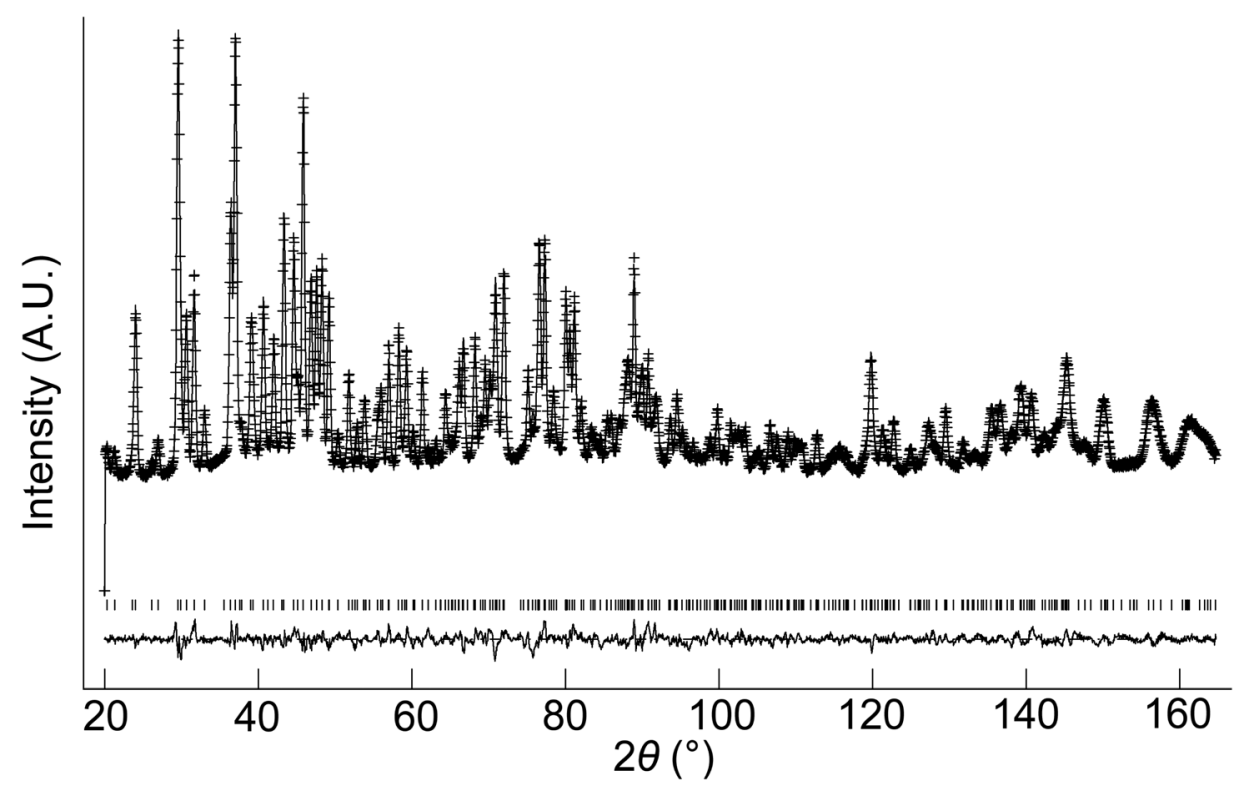

Fig. 6 Observed, calculated and difference neutron diffraction profiles for hydrated $\mathrm{La}_{9.6} \mathrm{Si}_{6} \mathrm{O}_{26.4}$. 
(a)

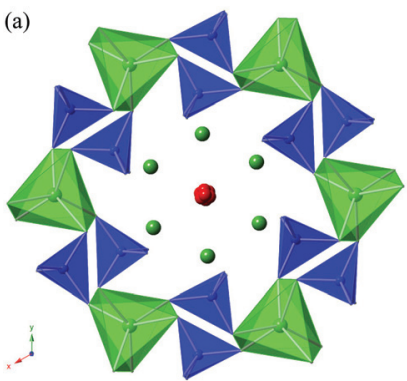

(b)

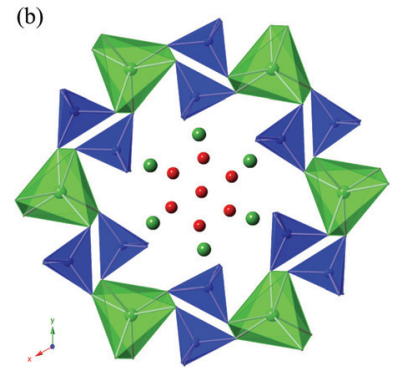

Fig. 7 Illustration of the structures of (a) as-prepared and (b) hydrated $\mathrm{La}_{9.6} \mathrm{Si}_{6} \mathrm{O}_{26.4}$ (blue tetrahedra $=\mathrm{SiO}_{4}$, green trigonal metaprisms $=\mathrm{LaO}_{6}$, green spheres $=\mathrm{La}$, red spheres $=0$ ) showing the presence of the interstitial oxide ion site close to the centre of the oxide ion channel for the former, while there is a significant deviation of this interstitial site away from the channel centre for the latter.
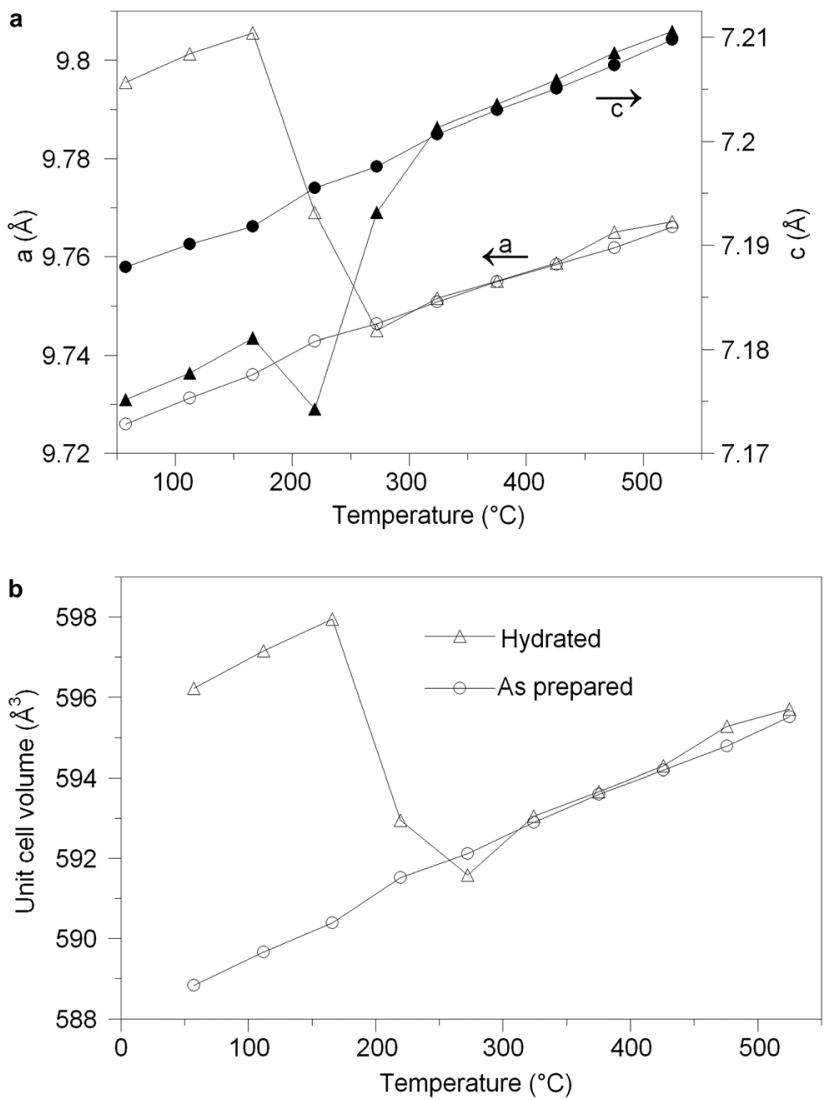

Fig. 8 (a) Cell parameter variation versus temperature for the as prepared (circle) and hydrated (triangle) $\mathrm{La}_{9.6} \mathrm{Si}_{6} \mathrm{O}_{26.4}$ on heating. (b) Cell volume variation versus temperature for the as prepared (circle) and hydrated (triangle) $\mathrm{La}_{9.6} \mathrm{Si}_{6} \mathrm{O}_{26.4}$ on heating.

interstitial oxide ion defects with the $\mathrm{MO}_{4}$ tetrahedra (for the germanate systems, the ${ }^{17} \mathrm{O}$ NMR data indicated that the presence of interstitial oxide ions led to the formation of $\mathrm{GeO}_{5}$ units $^{49}$ ). This closer association may explain the higher acti-

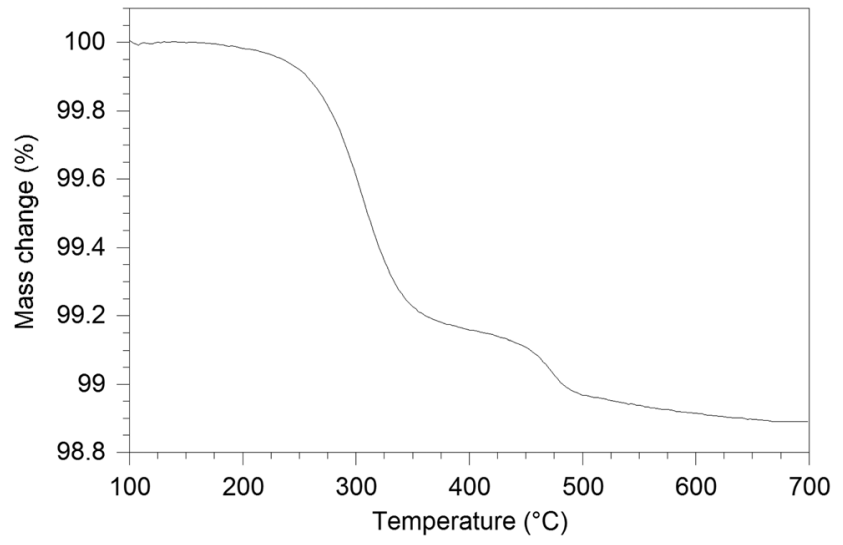

Fig. 9 TG profile of hydrated $\mathrm{La}_{9.6} \mathrm{Si}_{6} \mathrm{O}_{26.4}$.

vation energies for oxide ion conduction for the germanate compared to the silicate apatites, with a degree of trapping of the oxide ion interstitials due to this association. This trapping contribution is supported by recent high temperature Raman studies on germanate apatites. ${ }^{43}$

\section{Conclusions}

In this work, we have provided a detailed account of the structures of both as prepared and hydrated $\mathrm{La}_{9.6} \mathrm{Si}_{6} \mathrm{O}_{26.4}$ and $\mathrm{La}_{8} \mathrm{Sr}_{2} \mathrm{Si}_{6} \mathrm{O}_{26}$. The results show that higher hydration levels are possible for the $\mathrm{La}_{9.6} \mathrm{Si}_{6} \mathrm{O}_{26.4}$ system, and the study provides an important clarification of the effect of oxide ion content on the interstitial oxide ion position. In particular, the structural studies show that for low oxide ion excess, the interstitial oxide ion position appears to lie close to the channel centre, while on increasing the interstitial oxide ion levels, there is progressive displacement of the oxide ions towards the channel periphery. This can be explained by the need for additional displacement to prevent short $\mathrm{O}-\mathrm{O}$ interactions, and is allowed by the flexibility of the apatite framework: in particular a decrease in the $\mathrm{LaO}_{6}$ metaprism twist angle allows the expansion of the apatite channels to accommodate more interstitial oxide ions. The NMR studies show that the oxide ions of the $\mathrm{SiO}_{4}$ are readily exchangeable, similar to reports for Ge based apatites. These results suggest that oxide ion exchange processes with the $\mathrm{SiO}_{4}$ are likely to have a contribution to the oxide ion conductivity, and this would help to explain the observation of significant oxide ion conduction perpendicular to the channels from single crystal studies.

\section{Acknowledgements}

We would like to thank EPSRC and the University of Birmingham for DTG financial support of studentships for BJC and JFS, and we thank EPSRC for the funding of EP/I003932, EP/ 
(a)
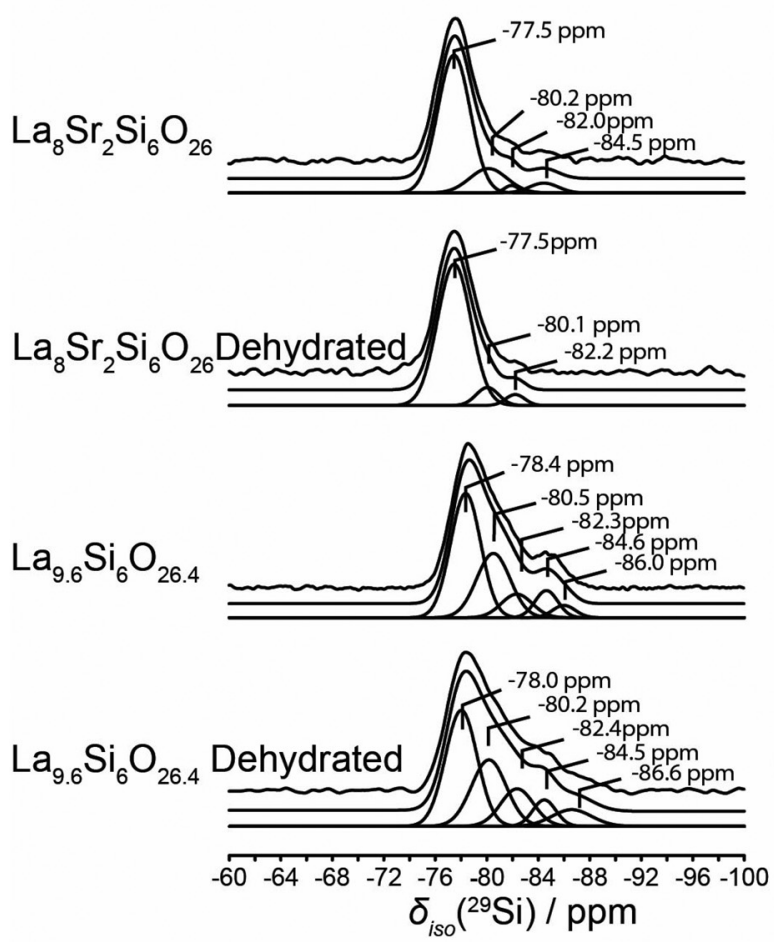

(c)

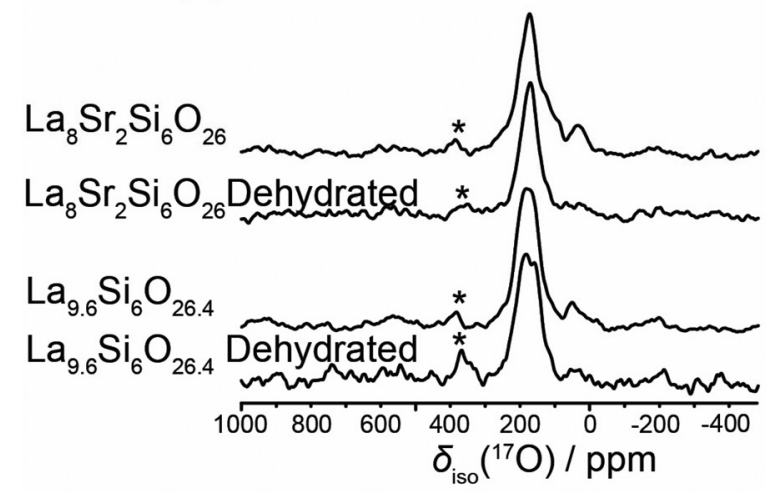

(b)

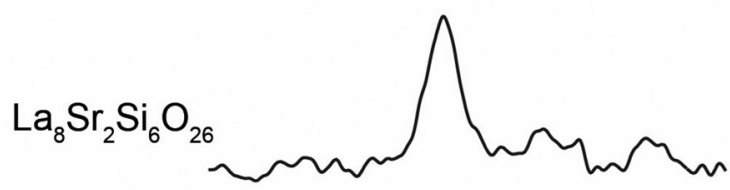

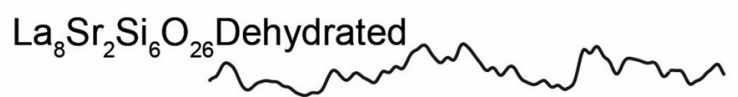

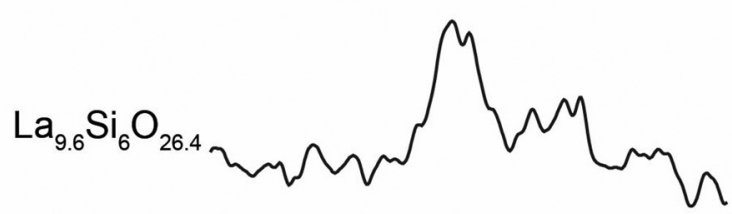

Fig. 10 The (a) ${ }^{29} \mathrm{Si}$ MAS and (b) $29 \mathrm{Si}$ CPMAS NMR data $\left(B_{0}=9.40 \mathrm{~T}, \nu_{0}=59.61 \mathrm{MHz}, \nu_{\mathrm{r}}=10 \mathrm{kHz}\right),(\mathrm{c}){ }^{17} \mathrm{O}$ MAS NMR data $\left(B_{0}=14.1 \mathrm{~T}, \nu_{0}=\right.$ $\left.81.30 \mathrm{MHz}, \nu_{\mathrm{r}}=30 \mathrm{kHz}\right)$, and (d) ${ }^{1} \mathrm{H}$ MAS NMR data $\left(B_{0}=14.1 \mathrm{~T}, \nu_{0}=600.13 \mathrm{MHz}, \nu_{\mathrm{r}}=30 \mathrm{kHz}\right)$ data from the hydrated $\mathrm{La}_{8} \mathrm{Sr}_{2} \mathrm{Si}_{6} \mathrm{O}_{26}$, dehydrated $\mathrm{La}_{8} \mathrm{Sr}_{2} \mathrm{Si}_{6} \mathrm{O}_{26}$, hydrated $\mathrm{La}_{9.6} \mathrm{Si}_{6} \mathrm{O}_{26.4}$ and dehydrated $\mathrm{La}_{9.6} \mathrm{Si}_{6} \mathrm{O}_{26.4}$ systems. The asterisk on each spectrum in (c) denotes a background signal from the $\mathrm{ZrO}_{2}$ rotor material.

G009929 and EP/I004114/1. We would like to express thanks to SINQ for neutron diffraction time and Vladimir Pomjakushin for help with the neutron diffraction experiments on the $\mathrm{La}_{9.6} \mathrm{Si}_{6} \mathrm{O}_{26.4}$ system, and to ISIS at the Rutherford Appleton Laboratory for the provision of neutron diffraction beam time for the neutron diffraction experiments on the $\mathrm{La}_{8} \mathrm{Sr}_{2} \mathrm{Si}_{6} \mathrm{O}_{26}$ system. JVH and PRS thank Dr Thomas Kemp for his assistance with the acquisition of some of the solid state MAS NMR data. JVH thanks EPSRC and the University of Warwick for partial funding of the solid state NMR infrastructure at
Warwick. PRS and JVH thank the University of Birmingham and the Birmingham Science City for the Bruker D8 diffractometer, Netzsch STA 449 F1 Jupiter Thermal Analyser and some solid state MAS NMR instrumentation used in this research which were obtained through the Birmingham Science City Advanced Materials Project 1: Creating and Characterising Next generation Advanced Materials project, with support from Advantage West Midlands (AWM) and partial funding from the European Regional Development Fund (ERDF). 


\section{References}

1 A. Orera and P. R. Slater, Chem. Mater., 2010, 22, 675.

2 A. J. Jacobson, Chem. Mater., 2010, 22, 660.

3 S. Nakayama, H. Aono and Y. Sadaoka, Chem. Lett., 1995, 431.

4 S. Nakayama, M. Sakamoto, M. Higuchi and K. Kodaira, J. Mater. Sci. Lett., 2000, 19, 91.

5 H. Arikawa, H. Nishiguchi, T. Ishihara and Y. Takita, Solid State Ionics, 2000, 136-137, 31.

6 S. Tao and J. T. S. Irvine, Mater. Res. Bull., 2001, 36, 1245.

7 J. E. H. Sansom, D. Richings and P. R. Slater, Solid State Ionics, 2001, 139, 205.

8 L. Leon-Reina, M. E. Martin-Sedeno, E. R. Losilla, A. Caberza, M. Martinez-Lara, S. Bruque, F. M. B. Marques, D. V. Sheptvakov and M. A. G. Aranda, Chem. Mater., 2003, 15, 2099.

9 E. J. Abram, C. A. Kirk, D. C. Sinclair and A. R. West, Solid State Ionics, 2005, 176, 1941.

10 J. R. Tolchard, P. R. Slater and M. S. Islam, Adv. Funct. Mater., 2007, 17, 2564.

11 J. R. Tolchard, M. S. Islam and P. R. Slater, J. Mater. Chem., 2003, 13, 1956.

12 L. Leon-Reina, E. R. Losilla, M. Martinez-Lara, M. C. Martin-Sedeno, S. Bruque, P. Nunez, D. V. Sheptyakov and M. A. G. Aranda, Chem. Mater., 2005, 17, 596.

13 L. Leon-Reina, E. R. Losilla, M. Martinez-Lara, S. Bruque, A. Llobet, D. V. Sheptyakov and M. A. G. Aranda, J. Mater. Chem., 2005, 15, 2489.

14 V. V. Kharton, A. L. Shaula, M. V. Patrakeev, J. C. Waerenborgh, D. P. Rojas, N. P. Vyshatko, E. V. Tsipis, A. A. Yaremchenko and F. M. B. Marques, J. Electrochem. Soc., 2004, 151, A1236.

15 J. E. H. Sansom, J. R. Tolchard, D. Apperley, M. S. Islam and P. R. Slater, J. Mater. Chem., 2006, 16, 1410.

16 E. Kendrick, M. S. Islam and P. R. Slater, J. Mater. Chem., 2007, 17, 3104.

17 Y. Masubuchi, M. Higuchi, S. Kikkawa, K. Kodaira and S. Nakayama, Solid State Ionics, 2004, 175, 357.

18 S. Celerier, C. Laberty-Robert, J. W. Long, K. A. Pettigrew, R. M. Stroud, D. R. Rolison, F. Ansart and P. Stevens, Adv. Mater., 2006, 18, 615.

19 L. Leon-Reina, J. M. Porras-Vasquez, E. R. Losilla and M. A. G. Aranda, J. Solid State Chem., 2007, 180, 1250.

20 E. Kendrick, J. R. Tolchard, J. E. H. Sansom, M. S. Islam and P. R. Slater, Faraday Discuss., 2007, 134, 181.

21 E. Kendrick and P. R. Slater, Mater. Res. Bull., 2008, 43, 2509.

22 E. Kendrick and P. R. Slater, Mater. Res. Bull., 2008, 43, 3627.

23 S. S. Pramana, W. T. Klooster and T. J. White, Acta Crystallogr., Sect. B: Struct. Sci., 2007, 63, 597.

24 S. S. Pramana, W. T. Klooster and T. J. White, J. Solid State Chem., 2008, 181, 1717.

25 E. Kendrick, M. S. Islam and P. R. Slater, Chem. Commun., 2008, 715 .
26 A. Orera, E. Kendrick, D. C. Apperley, V. M. Orera and P. R. Slater, Dalton Trans., 2008, 5296.

27 E. Kendrick and P. R. Slater, Solid State Ionics, 2008, 179, 981.

28 P. J. Panteix, I. Julien, P. Abelard and D. Bernache-Assolant, Ceram. Int., 2008, 34, 1579.

29 T. Iwata, K. Fukuda, E. Bechade, O. Masson, I. Julien, E. Champion and P. Thomas, Solid State Ionics, 2008, 178, 1523.

30 R. Ali, M. Yashima, Y. Matsushita, H. Yoshioka, K. Okoyama and F. Izumi, Chem. Mater., 2008, 20, 5203.

31 J. R. Tolchard and P. R. Slater, J. Phys. Chem. Solids, 2008, 69, 2433.

32 E. Kendrick and P. R. Slater, Mater. Res. Bull., 2008, 43, 3627.

33 A. Orera and P. R. Slater, Solid State Ionics, 2010, 181, 110.

34 E. Kendrick, K. S. Knight and P. R. Slater, Mater. Res. Bull., 2009, 44, 1806.

35 J. M. Porras-Vazquez, E. R. Losilla, L. Leon-Reina, D. Marrero-Lopez and M. A. G. Aranda, J. Am. Ceram. Soc., 2009, 92, 1062.

36 C. Bonhomme, S. Beaudet-Savignat, T. Chartier, P.-M. Geffroy and A.-L. Sauvet, J. Eur. Ceram. Soc., 2009, 29, 1781.

37 A. Al-Yasari, A. Jones, D. C. Apperley, D. Driscoll, M. S. Islam and P. R. Slater, J. Mater. Chem., 2009, 19, 5003.

38 E. Bechade, O. Masson, T. Iwata, I. Julien, K. Fukuda, P. Thomas and E. Champion, Chem. Mater., 2009, 21, 2508.

39 S. Guillot, S. Beaudet-Savignat, S. Lambert, R.-N. Vannier, P. Roussel and F. Porcher, J. Solid State Chem., 2009, 182, 3358.

40 E. Kendrick, A. Orera and P. R. Slater, J. Mater. Chem., 2009, 19, 7955.

41 A. Orera, D. Headspith, D. C. Apperley, M. G. Francesconi and P. R. Slater, J. Solid State Chem., 2009, 182, 3294.

42 T. J. White and Z. L. Dong, Acta Crystallogr., Sect. B: Struct. Sci., 2003, 59, 1.

43 A. Orera, M. L. Sanjuán, E. Kendrick, V. M. Orera and P. R. Slater, J. Mater. Chem., 2010, 20, 2170.

44 K. Fukuda, T. Asaka, M. Oyabu, D. Urushihara, A. Berghout, E. Bechade, O. Masson, I. Julien and P. Thomas, Chem. Mater., 2012, 24, 4623.

45 K. Fukuda, T. Asaka, N. Ishizawa, H. Mino, D. Urushihara, A. Berghout, E. Bechade, O. Masson, I. Julien and P. Thomas, Chem. Mater., 2012, 24, 2611.

46 K. Matsunaga and K. Toyoura, J. Mater. Chem., 2012, 22, 7265.

47 H. Kiyono, Y. Matsuda, T. Shimada, M. Ando, I. Oikawa, H. Maekawa, S. Nakayama, S. Ohki, M. Tansho, T. Shimizu, P. Florian and D. Massiot, Solid State Ionics, 2012, 228, 64.

48 K. Fukuda, T. Asaka, R. Hamaguchi, T. Suzuki, H. Oka, A. Berghout, E. Bechade, O. Masson, I. Julien, E. Champion and P. Thomas, Chem. Mater., 2011, 23, 5474.

49 P. M. Panchmatia, A. Orera, G. J. Rees, M. E. Smith, J. V. Hanna, P. R. Slater and M. S. Islam, Angew. Chem., Int. Ed., 2011, 50, 9328. 
50 A. Orera, T. Baikie, E. Kendrick, J. F. Shin, S. Pramana, R. Smith, T. J. White, M. L. Sanjuán and P. R. Slater, Dalton Trans., 2011, 40, 3903.

51 T. An, T. Baikie, F. Wei, S. S. Pramana, M. K. Schreyer, R. O. Piltz, J. F. Shin, J. Wei, P. R. Slater and T. J. White, Chem. Mater., 2013, 25, 1109.

52 S. Nakayama, Y. Higuchi, M. Sugawara, A. Makiya, K. Uematsu and M. Sakamoto, Ceram. Int., 2014, 40, 1221.

53 G. Ou, X. R. Ren, L. Yao, H. Nishijima and W. Pan, J. Mater. Chem. A, 2014, 2, 13817.

54 H. Yoshioka, H. Mieda, T. Funahashi, A. Mineshige, T. Yazawa and R. Mori, J. Eur. Ceram. Soc., 2014, 34, 373.

55 W. Liu, T. Tsuchiya, S. Miyoshi, S. Yamaguchi, K. Kobayashi and W. Pan, J. Power Sources, 2014, 248, 685.
56 C. Argirusis, E. Jothinathan, G. Sourkouni, O. Van der Biest and F. Jomard, Solid State Ionics, 2014, 257, 53.

57 M. M. Vieira, J. C. Oliveira, A. L. Shaula, B. Trindade and A. Cavaleiro, Surf. Coat. Technol., 2014, 247, 14.

58 A. Pons, J. Jouin, E. Bechade, I. Juilien, O. Masson, P. M. Geffroy, R. Mayet, P. Thomas, K. Fukuda and I. Kagomiya, Solid State Sci., 2014, 38, 150.

59 T. An, T. Baikie, M. Weyland, J. Shin, P. Slater, J. Wei and T. White, Chem. Mater., 2015, 27, 1217.

60 T. An, A. Orera, T. Baikie, J. S. Herrin, R. O. Piltz, P. R. Slater, T. J. White and M. L. Sanjuán, Inorg. Chem., 2014, 53, 9416.

61 A. C. Larson and R. B. Von Dreele, Los Alamos National Laboratory, Report. No LA-UR-86-748, 1987. 